\title{
Colour-Related Idiomatic Expressions in English and Kurdish
}

\author{
Najat O. Kareem Romi ${ }^{1}$ \\ ${ }^{1}$ Department of English Language, Faculty of Humanities and Social Sciences, Koya University, Kurdistan Region, Iraq
}

\begin{abstract}
Colour is a powerful communication tool and can convey different positive and negative messages. Apart from their denotative meanings, colours have different connotations in different languages and cultures. Many of these connotations are very clearly observed in their use of colour idiomatic expressions. This study explores the different meanings and connotations of the basic colour terms and their usage in idiomatic expressions in English and Kurdish to find out areas of similarity and difference between them. To this end data were collected from different English dictionaries and from English idiom dictionaries; while for the Kurdish idiomatic expressions data were collected from Kurdish idiom books (See methodology $4.1 \& 4.2$ ). The findings obtained from the analysis of the data show that despite similarities in the number of the basic colour terms and their general meanings and connotations in the two languages, the symbolic use of the colour terms in idiomatic expressions is, to a great extent, culture and language specific.
\end{abstract}

KEY WORDS: Basic Colour Terms, Connotations, Colour-Related Idiomatic Expressions, Culture-Specific, Different Languages

\section{INTRODUCTION}

Everything around us has a certain colour or certain colours. Our natural environment, the clothes we wear, the food we eat, the furniture and tools we use, are all colourful so that colour has dominated almost all aspects of our life. In this respect, Douma (1988, n.p.) states that:

Color is a microconsciousness. Like our senses of taste and smell, color helps us to understand the world around us. While it gives us elementary survival skills, color also enriches our lives, allowing us to appreciate everything from the beauty of a rainbow, to the aesthetic pleasure of a painting.
Colours also influence our physical and mental health and our emotions. Goethe, in his Theory of Colour (1840), states that particular colours arouse particular feelings in us and that colours are a source of delight to people in general. He further states that "the eye requires it as much as it requires light" (Goethe, 1840, pp. 304-5).

Similarly, Pathak (2012, p. 3) argues that "colours for us are not just an important part of our visual senses but share a deeper relationship with our brain and psychology than just helping us to identify objects". She mentions that different colours arouse different positive and negative

Koya University Journal of Humanities and Social Sciences (KUJHSS)

Volume 2, Issue 1, 2019

Received 20 April 2018; Accepted 10 March 2019

Regular research paper: Published 25 May 2019

Corresponding author's e-mail: najat.romi@koyauniversity.org

Copyright (2019 Lect. Najat Omar Kareem, This is an open access article distributed under the Creative Commons Attribution License. - 0CC BY-NC-ND 4 
emotions within us and affect the human psychology in different ways. For example, she further adds, "colours can change actions, cause a reaction, irritate or sooth the eyes and give rise to a whole lot of emotions within us".

Since the prehistoric era, humans have interacted with colours so that every culture has attached different symbolic values and meanings to colours and although colours often share universal associations, the perception and interpretation of colours differ from one culture to another. This difference has been clearly reflected in the figurative use of colour in the different languages.

This study focuses on colour-related idiomatic expressions in English and Kurdish. English, as identified by Berlin and Kay (1969), has eleven basic colours namely, red, yellow, green, blue, black, white, gray, orange, brown, pink, and purple. The same stock of basic colours is also found in Kurdish (Berlin and kay, 1991, p.2).

The study adopts a midway i.e. an eclectic approach between the Universalists' and the Relativists' views on colour (See section 5.3). As far as colour categorization and terminology are concerned, the Universalists' view is applicable since both English and Kurdish have the same stock of basic colours with terms for each, while in terms of perception and symbolic meaning of these colours, the study is an attempt to prove the Relativists' view which proposes that colour perception and meanings are determined by the native language and culture.

\section{AIM OF THE STUDY}

The study attempts to verify the hypothesis that despite similarities in the number of the basic colour terms and in their general meanings in English and Kurdish, the perception of colours and their symbolic use in idiomatic expressions in the two languages are, to a great extent, culture and language specific.

\section{LIMITATIONS OF THE STUDY}

This study is limited in several ways. Firstly, Kurdish language here is restricted to the Central Kurdish dialect ${ }^{1}$ (Sorani dialect) used in Kurdistan Region/ Iraq. Secondly, it only deals with the basic colour terms in general rather than the different shades and hues of these colours and finally, the study deals with six of the basic colour terms namely (white, black, red, green, yellow and blue) based on the fact that these colours are richer in idiomatic expressions compared to the others in both languages and Kurdish has no idiomatic expressions with orange, brown and pink.

\section{METHODOLOGY}

\subsection{Data Collection}

Data on the English-colour related expressions have been collected from different English dictionaries ${ }^{2}$. As far as the Kurdish colour-related expressions are concerned, data have been collected from sources on Kurdish idioms ${ }^{3}$. However, due to lack of sources on the subject in Kurdish, the researcher, being a native speaker of Kurdish, has mostly depended on her own intuition, background information and experience and on other experienced Kurdish informants ${ }^{4}$.

\subsection{Data Organization and Analysis}

The organization of the data is done by giving a general explanation of the meanings and connotations of each colour with examples of idiomatic expressions and their symbolic meanings in English and the same is done for Kurdish. The analysis of the data has been done by comparing the general symbolic meanings of each colour in both languages and then comparing the idiomatic expressions for each colour to find out how similar or different they are in meaning and form in the two languages and also to find out how frequently each colour is used figuratively in each language. The idiomatic expressions which have total or partial equivalents in the two languages have been marked with asterisks.

\section{BACKGROUND}

\subsection{Colour Vision Theory}

Almost all languages have some basic colour terms and the study of colour has a long history. According to $\mathrm{He}$, the study of colour as a basic cognitive domain dates back to nearly 2500 years ago (He, 2011, p. 1805). 
The Greek philosophers were the first to start thinking about vision and colours. Their studies centred around two opposing views: the extramission or (extramittist) and the intromission or (intromittist). The extramission theory emphasizes the active role of the eye i.e. colour vision occurs when the eyes send out rays of light to an object, while the intromission theory emphasizes the passive role of the eye i.e. colour vision occurs when the objects send out light rays and these rays are received by the eyes (Crone, 1999, p.1; Swenson, 2010 p.29-30). For example, Plato describes vision as "a combination of light from within i.e. from the eye and light without", while Aristotle believed that vision was the "passive reception, by the eye, of an action originating in objects, thus, he was originator of the scientific optics, as propounded 2000 years later by Newton" (Koelbing, 1988, p. 176).

The theory of vision and colours was further developed by two other Greek philosophers, Empedocles and Democritus. Empedocles (490-435 $\mathrm{BC})$ believed that everything was generated from four elements: fire, water, air and earth and that these elements were represented by the sun, the sea, the sky and the earth, and that the colours and shapes came into being by mixing these four elements. Empedocles was both an extramittist and intromittist. He compared the eyes to a lantern that shot fire (extramission view); however, he also believed that objects produced reflections that were received by the eyes (intromission view) and that colours were produced when fire from the eye met with the rays emitted by the objects. Democritus was an intromittist and believed that the visual world came to us and that vision occurred as a result of the meeting between the image of the outside object and the reflection from the eyes (Crone, 1999, p.2).

The scientific study of colour began in the seventeenth century when Sir Isaac Newton (16421727) presented his optics on colour vision. By using a prism, Newton observed that white light consisted of all the colours of the rainbow and that the "colours that composed white light could not be further subdivided, but they could be recombined to form white light". He concluded that "colour is not the product of the external objects we see, but is a property of the eye itself" (Wagner and Kline, 2002, para.6). Newton produced the first colour wheel which consisted of seven basic colours, namely red, orange, yellow, green, blue, indigo and violet, while the other colours, as he suggested, were derived from these seven colours (Zelanski and Fisher, 2005, pp. 6-7).

A century later, Goethe started his experiments with optical prisms, but while Newton looked at colours from a physical point of view, Goethe looked at colours from a physiological point of view. He focused on the active role of the eye in visual perception (Koelbing, 1988). Goethe argued that colours resulted from interaction of light and darkness. He argued that light and darkness were necessary to the production of color and that "color itself is a degree of darkness". Goethe believed that there were only two pure colours-blue and yellow, while the rest were mixtures or degrees of these two colours. (Goethe, 1840, pp. xIii-xIiii).

The early theories of color were based on speculation. However, with more data available, the theories have been able to explain how the brain really perceives color (Domma, 2008). Two of these theories that emerged in the $19^{\text {th }}$ century were the trichromatic theory also known as Young-Helholtz theory [Reference to the authors Thomas Young and Hermann von Helholtz], and the opponent process theory. According to the trichromatic theory of color vision, three receptors in the retina are responsible for the perception of color. One receptor is sensitive to the color green, another to the color blue, and a third to the color red. The combinations of these three colors produce all the colors that we are capable of perceiving. The opponent process theory developed by Ewald Hering states that "our ability to perceive color is controlled by three receptor complexes with opposing actions. These three receptors complexes are the red-green complex, the blue-yellow complex, and the black-white complex". It further states that these cells can only detect the presence of one color at a time and that there are some color combinations that people never see. For example, while we often see greenish-blue or bluish-reds, we do not see reddish-green or yellowish-blue because the two colors oppose one another (Cherry, 2018, para $1 \& 2)$. However, these theories could not be proved until the introduction of three different cone photo pigments in the twentieth century (Wagner and Kline, 2000).

The above explanation shows that different scholars looked at colour vision from different 
perspectives. Some scholars have made connections between colour and natural elements like the sky, the earth, water and fire, which may have, in later stages, led to the development of processes, which has given colour vision the quality of being universal. These approaches have resulted in different linguistic views on colour perception and terminology. Among these views are two main opposing stands taken by the Relativists and the Universalists (See 5.3)

\subsection{Colour Categories}

According to De Bortoli and Maroto, (2001, p.3), human beings are able to see over 7 million colours and that these colours are built from a stock of basic colours. Based on their relation to each other, colours are classified into the following categories:

1. Primary colours. Red, blue and yellow are the basis of all other shades, and cannot be created by combining other colours. The combination of the three colours in equal amounts will produce black.

2. Secondary Colours. These are the colours that are produced from mixing two primary colours together. There are three secondary colours: violet (made up of red and blue); orange (made up of red and yellow) and green (made up of yellow and blue).

3. Tertiary Colours. These are created by mixing one primary with one secondary colour. There are six tertiary colours: saffron (red and orange); lime (yellow with green); lavender (blue with violet); purple (red with violet); amber (yellow with orange) and turquoise (blue with green).

The combination of white or black with the above-mentioned colours produces tints and shades. The depth of a colour is called Tone. Neutrals refer to subtle shades from the palest colours (beige, cream), and are used to balance vibrant or rich colours. Cold colours are those with a high proportion of blue in their make-up, such as violet blue and some greens, and they have a calming effect. Warm colours have more red and yellow in their make-up. They are energizing (ibid).

\subsection{The Linguistic Perspective on Colour Perception and Terminology}

The study of colour-language which deals with the relationship between language and perception became a branch of linguistics in the late $19^{\text {th }}$ and early $20^{\text {th }}$ century (Gage, 1999, p. 11). According to Wardaugh (1986, p. 226), colour terminology has been used to find out the relationship between different languages and cultures and despite the fact that the colour spectrum consists of one physical continuum without any breaks, it has been divided into pieces and bits by different languages and different names have been given to these pieces e.g., green, blue, yellow, red, etc. He further adds that direct translation of colour words from one language to another can cause change in meaning.

Colour perception and terminology have been the subject of a long-standing debate in cognitive science. At one pole of this debate are the Relativists who argue that "our perception of the world is shaped by the semantic categories of our native language and that these categories vary across languages with little constraint" (Regier and Kay, 2009, p.1). This view is based on the SapirWhorf hypothesis which proposes that "thoughts and behavior are determined or are at least influenced by the semantic categories of the native language; therefore, people fail to perceive different colours because of language limitations" (De Bortoli\& Maroto, 2011, p. 4).

At the other pole are the Universalists who argue that there is "a universal repertoire of thought and perception that leaves its imprint on the languages of the world" (Regier and Kay, 2009, p.1). Both views have their proponents and opponents.

Palmer (1981, pp. 56-7) finds the relativists' arguments somehow unconvincing because, as he states, "if language classifies and categorises experience, it must do so on the basis of some language-independent characteristic of that experience". He further argues that even if the speakers of the different languages do not share the same picture of the universe, they must share some related characteristics; otherwise, he argues, we would not be able to investigate other languages or translate from one language to another. Thus, he rejects the idea of languages being completely different.

Among Universalist scholars, who challenged the Relativists' view are Brent Berlin and Paul Kay, who, in their 1969 study about basic colour terms, introduced the universal theory which proposes that "semantic universals do exist in the domain of colour vocabulary" and that these universals are evolutionary since they are related to the historical 
development of all languages. (Berlin and Kay, 1991:1) They further state that despite the fact that languages may differ in the number of their basic colour terms, there exists a stock of eleven basic colours from which languages draw their basic colours. Their study was based on data, collected from speakers of twenty different languages selected from a variety of language families. Berlin and Kay suggested that the number and use of the basic colour terms in a language were universally restricted. They also proposed a fixed order in which the number of these basic colours in a language determines what those terms would be. According to their theory, if a language has two colours, it will contain terms for black and white. If it has three, there will be a term for red, if it has four or five there will be terms for green and yellow, if it has seven, there will be a term for blue and if it has more than this, there will be terms for pink, purple, orange and gray but not in a particular order. Based on their study, they were able to identify eleven possible basic colour categories: white, black, red, green, yellow, blue, brown, purple, pink, orange, and gray. (Berlin\& Kay, 1991, p. 2).

The Berlin and Kay 1969 colour study was revised by many subsequent scholars e.g. (Kay, 1975; Kay and McDaniel, 1978; Kay and Kempton, 1984, and Kay, Berlin and Merrifield, 1991 cited in Saunders 1995, p. 21) but, as stated by Saunders (1995, p.21) none of these revisions has made any change in the general outline of the original Berlin and Kay theory.

Saunders (1995, p. 21) rejects the Berlin-Kay approach and believes that their theory "has made invisible the ethical, rhetorical and other sociohistorical processes with which it has created doctrine". And while the universalist scholars, Kay and McDaniel (1978, p.610) consider colour perception as the outcome of "a set of neurophysiological processes" that constitute the basis for the universal perception and understanding the meaning of the basic colour terms, and argue that their lexical categorization of colour is a universal biological process, Sounders (1995, p. 21) thinks that the Berlin and Kay sequence of basic colour terms is "governed by a hierarchy of immanent techno-socio triggers which prompt the lexicalization of primitive concepts" and she argues that their study is not biologically based because, as she sees it, their idea about colour evolution is not the one commonly used by biologists. (ibid, p. 33)
She further states that Berlin and Kay have tried to apply the English colour naming and mapping to other languages, which she finds inappropriate because, as stated by her, languages differ in the perception of colour and what is called blue in English may be called green in another language (ibid, p. 23). She also finds that Berlin and Kay theory has disregarded the relations between the world and language (ibid, p. 24).

Similarly, Lucy (1996, p.46) argues that the comparative work done on colour by Berlin and Kay and their supporters and also by other subsequent scholars completely apply the western conception and lexicalization of colour. He further argues that these studies do not consider linguistic differences and suggest that languages are only reflection of reality.

Douma (2008, n.p.) supports Sounders's and Lucy's view and states that "our vision is an active process, depending as much on the operations of the brain as on the external, physical, environment".

On the other hand, Regier and Kay (2009, p.1) have come to a new conclusion about the Universalist-Relativist debate. They suggest that colour names affect colour perception " mainly in the right visual field, and less in the left" and that "colour naming in different languages reflects universal tendencies but with a degree of native language convention". Therefore, they believe that Whorf or the Relativists are partly right in their approach. Regier and Kay think that these findings may put an end to the current debate over language and thought in the field of colour (ibid).

Gage (1999, p. 21) considers the studies of colour to be incomplete because they have not looked at both the art and science of colour together, hence, they have missed many important aspects of colour. $\mathrm{He}$ also states that many scholars have only considered 'the physiological processing of light by the eye but have ignored the mind which apprehends it'. According to Gage, colour is "the attribute of visual experience that can be described as having quantitatively specifiable dimensions of hue, saturation and brightness." and he considers colour as "a subjective outcome of an objective process" (ibid).

Based on what Regier and Kay (2009) and Gage (1999) say about colour, it can be concluded that in order to have a comprehensive view on colour perception, studies on colour should take a more holistic approach rather than looking at it from one 
angle. This indicates that the Universalists and the Relativists have complementary rather than opposing views. The Universalists look at colour from a biological perspective while the Relativists look at it from a linguistic perspective and combining the two will give a comprehensive picture about colour perception.

\subsection{Colour and culture}

Despite the universal interpretations of colour terms, colours can have different meanings and interpretations to different people and cultures. This is so because as stated by He (2009, p. 160), the different national and cultural backgrounds, including traditions, habits, life experiences, aesthetics, etc. produce different colour connotations. Similarly, Pathak $(2012$, p. 8) believes that every society, culture and religion associates different colours with different ideas and concepts. She adds that "colour significance in different cultures is so deep rooted that it defines that object or idea. Hence, a colour can be a very strong indicator of that idea, concept, object or occasion in various cultures and religions" (Pathak, 2012, p. 8).

According to Foster (n.d., p.2), "connotations depend on experience". For example, she suggests, if whenever you go to a certain place, you are overcome with a feeling of sadness, you may associate the colours in that place with sadness. She adds that the predominant connotations in a certain culture are related to the collective experience and traditions of the people of that culture. For example, she suggests, for the British people, the colour green is associated with envy and jealousy, as in green with envy, while for people living in the desert, green can mean pastures where there is water, hence, it can be a symbol of life and hope. According to NPTEL $(2012,6)$, cultural colour associations can differ widely. For example, in the west it is a tradition for brides to wear a white dress, in Anglo-American culture, wearing blue is also traditional, while in some Asia/Pacific countries, brides wear red. In the west, people wear black for funerals, while in India it is common to wear white. In Western cultures, purple is often associated with royalty, but it is a colour of mourning in Thailand (ibid).

On the other hand, colour perception and preferences can be influenced by several cultural and non-cultural factors including age, gender, religion, lifestyle, fashion, health, politics, economy, climate, etc. For example, according to De Bortoli and Maroto (2001, p. 5), children prefer bright red to express their anger and their desire to destroy, while black or the darkness of the night causes them unpleasant and sad feelings. With the passage of time this violence of behavior disappears and the colour choices change into softer ones. This process continues and as people get old, they prefer subtle colours i.e less bright colours (ibid, p. 6). As far as gender is concerned, colour choices differ between men and women. In a study by Radeloff (1990, cited in De Bortoli and Maroto, 2001, p. 5), it was found that men and women had almost similar preferences with regard to light versus dark colours; however, in expressing their preference for bright and soft colours, women preferred soft colours while men preferred bright ones. Gage (1999, p. 33) mentions that there is a wide-spread believe about women being more discriminating in their use of colour than men and he links this to the fact that colour deficiencies in women's vision are less as compared to men.

Climate has also its effect on colour preference. According to a research by the psychologist E.R. Jaensch (cited in De Bortoli and Maroto, 2001, p. 4), people living in climates with a lot of sunshine prefer warm bright colours; while those from climates with less sunlight prefer cooler, less saturated colours (ibid). Colours also influence marketing and products' desirability. James Mandle, a colour consultant, changed the colour of Ty-d-Boles toilet bowl cleanser bottle from light blue and green to stark white letters on a dark background to symbolize strength and cleanliness. In the 18 months that followed the sales jumped $40 \%$ (ibid, p. 8 )

In the same way, Palmer (1981, p. 57) states that the "colour system is not solely based on the physical features of colour but is partly determined by the cultural need, the need, for instance, of distinguishing living and dead bamboo, one green, the other red". He further adds that colour words are not always used in their denoted meaning. For example, the colour of dried beans is green but not referred to as green peas, while green is often used to mean unripe fruit. In the same way, white, when used in relation to coffee, is brown, it is yellow when relating to wine and it is pink when referring to people (ibid: 75).

As the above examples show, culture plays an important role in the perception and understanding 
of the meaning of the different colours and lack of awareness of the cultural significance of a particular colour, may lead to misunderstanding and often to offending a whole community.

\subsection{The idiomatic use of colours in language}

An idiom, according to the Oxford Advanced Learner's Dictionary ( $8^{\text {th }}$ ed. 2010), is "a group of words whose meaning is different from the meaning of the individual words". Idiomatic expressions are "expressions that are natural to the native speakers of a language" (ibid). The use of colour terms in idiomatic expressions is a very common phenomenon in different languages and cultures.

The use of colours in combination with other words and according to their linguistic and cultural contexts helps to better realize their connotative meanings. In this respect, Philip (2011, p. 26) states that "colours are imbued with a bewildering range of connotative and associative meanings, and these are reflected in language in two principal ways: in fixed and semi-fixed phrases such as idioms and metaphorical collocations, and in language play". According to De Bortoli and Maroto (2001, p. 11), in most languages colours are used to express moods and feelings and in almost all languages there are numerous colour-related idiomatic expressions, which, in most cases, have no equivalents in other languages and translating them will result in loss of their meaning. For example, the English idiom to feel blue meaning (to feel sad) has no equivalent in other languages. Similarly, Salim and Mehawesh (2013, p. 107) argue that "color idiomatic expressions express the uniqueness of the language and culture they originated in".

English and Kurdish are both rich in the use of colours in idiomatic expressions based on their cultures and their perception of colours. Below is an explanation of six of the basic colours (white, black, red, green, yellow and blue) with their symbolic meanings and examples of idiomatic expressions for each colour in each language. The expressions with asterisks are the ones which have total or partial equivalents in the two languages.

\section{White: Spi}

In contrast to black, white is a symbol of moral and physical purity. To ${ }^{*}$ whiten something is to make it pure, and a morally pure person can be said to be *white-hearted. This metaphorical association can be traced back to Old English hwit, which contrasts with black and its association with evil and immorality (Anderson and Bramwell, 2014, p. 146).

In general, white indicates light. It has positive connotations like: purity, birth, cleanliness, sterility, innocence, and peace (Kleynhans, 2007, 49). Expressions indicating these connotations in English are: *as white as a sheet/ as white as the driven snow meaning (very white, indication of cleanliness and innocence); a *white dove is (a symbol of peace); white hope refers to (a person who is expected to bring success to a team, organization, etc.); whiter than white (of a person, completely honest and morally good). He (2009, 161) states that in English, white often stands for hope, peace, happiness and light as indicated by the idiom's white day (a lucky day); days marked with a white stone (the happy days of one's life).

Dunn, $(2014,5)$ states that white helps to empty the mind of bad thoughts and helps for fresh beginnings and clarity of mind and it is the colour worn by doctors, matrons, caterers and all workers of institutions where neatness is the watchword as a symbol of cleanliness. Brides traditionally wear white gowns as a sign of purity and virginity (ibid). An example of this is white wedding (a traditional wedding, especially in a church, where the bride wears a white dress). According to Makarevicius (2014), Jewish, Christian and Hindu religions use the color white in rituals to indicate purity, chastity, virginity and inner peace. He argues that the white dove is associated with a state of perfection, peace, and blessedness. And it is also the flag color used in hospitals and health care facilities throughout the world (ibid).

However, Kleynhans $(2007,49)$ states that white also carries some negative connotations such as surrender, cover-up and perversion of justice. These connotations can be indicated by the idioms * white flag (surrender); whitewash (an attempt to hide unpleasant things about somebody or something); *white lie (a harmless or small lie especially one that you tell to avoid hurting somebody or to avoid a bad situation to happen); white witch (a person who does magic that does not hurt other people).

Other negative meanings associated with white as indicated by some idiomatic expressions are cowardice and fear as in white feather (a timid or a coward person); as white as a ghost (very white because of fear); * to go white/ to turn as white as a 
sheet (to turn pale because of a shock, being frightened or because of illness). White can also indicate unpleasant sounds as in white noise (a constant unpleasant noise), or it can be a reference to an expensive but useless thing as in white elephant (a thing that is useless and no longer needed although it may have cost a lot of money). Also, white trash is a reference to (the poor white people especially those who live in southern US).

White has also some neutral connotations as in the following expressions:*white arms (cold weapons), White Christmas (a Christmas during which there is snow on the ground); white collar (a person working in an office); White Hall (a street in London where there are many government offices); The White House (The official home of the US president at Washington DC); white knight (a person or organization that rescues another company from being bought by another company at too low a price).

In Kurdish, as the idiomatic expressions show, most of the connotations of white are positive and some of them are similar to the English ones (see the ones with asterisks). For example, as in English and other languages, *kotri spi (white dove) in Kurdish is also a symbol of peace. White is one of the colours of the flag of Kurdistan to symbolize peace, equality and freedom for all the different ethnicities and religions who live in Kurdistan Region (Izadi, 2008).

In Islam white indicates purity, cleanliness, hope, spirituality; therefore, it is used in religious rituals. For example, most Muslim Kurdish women wear white scarves especially when they pray and pilgrims wear white Ihram clothing during Haj or Umrah to indicate unity, equality and brotherhood. As in other cultures, white is worn by brides. Newborn babies are wrapped in white babygros, and dead bodies are wrapped in white shrouds before being buried.

White hair or beard is a symbol of experience and wisdom as indicated by rîş spi/ ser spi (having white beard/head (head here means hair i.e. a wise and experienced old man whom people consult and take advice from); bisik spi/ ser spi (of a woman, having white locks of hair meaning an old woman who is wise and experienced and whom people consult and take advice from); dem spi (whitemouthed, a person who has very good speaking and communication skills and is the mouthpiece of people).

White face for women is a symbol of chastity and virginity as in rût spi bi (May you keep a white face, meaning may you stay honest and chaste. Here white can be replaced by red to mean the same). White with red when used to describe a person (male or female) indicates health and beauty as in sur u spi (literally meaning having red and white complexion i.e. healthy and beautiful). White also indicates good luck, new start, optimism and hard work as in bexit spi (having white luck i.e. having good luck); heldanewey lapereyeki spi (to start a white page i.e. to leave all the previous problems behind and have a new start. The English equivalent is to turn a new page); parey spi bo roji reş (white coins for black days i.e. saving money for emergency situations); çaw spi bûn (of one's eyes to turn white i.e. to become very tired trying to achieve something).White is also a symbol of honesty and beauty as in *spi wek kaxez/ wek befir/wek kwarg/ wek penîr/ wek loke (as white as a sheet of paper/ as snow/ as mushroom/ as cheese/ as cotton (of a person's skin, very white, indication of beauty); *nawdil spi (white-hearted, honest and kindhearted); *spikirdnewe (to whiten something especially pots or dishes made of aluminum meaning to polish them); spibunewe (of the colour of cloth or clothes, to fade) dro spi kirdnewe (literally meaning to whiten a lie i.e. to refute a lie, which means to say something to prove that what somebody has said is a lie or not true); spikirdin (to make white, of fruit or vegetables to peel off the skin).

However, in Kurdish, white also carries some negative connotations such as disease, fear, lack of ability to do any work. For example, *spi herman/ spi helgeran (to turn white i.e. to turn pale because of a shock, or because of being frightened or because of illness); dest $\mathbf{u}$ pe spi, (literally meaning having white hands and feet i.e. lacking experience and ability to do any work). Other Kurdish idiomatic expressions with white include: *droy spi (white lie); *çeki spi (cold weapons); *alay spi (white flag, a sign of surrender).

The English and Kurdish idiomatic expressions with white show only few similarities (see the ones with asterisks) and some of them are very culture specific e.g. white Christmas, white collar, white knight, white elephant, etc. are related to English culture, while the use of white hands and feet to indicate lack of experience or white mouthed to mean a person 
with good communication skill, white face to indicate virginity are related to Kurdish culture.

\section{Black: Reş}

In most cultures black carries negative connotations as compared to positive ones. Anderson and Bramwell (2014, p. 144) see "a broad metaphorical association between black and badness or evil" while Chapman (2010) suggests that black is the strongest neutral color having both positive and negative connotations. Positively, it is associated with power, elegance, and formality. Negatively, as suggested by Chapman (2010), black can be associated with evil, death, and mystery and in many western countries, black is the traditional color of mourning and in some cultures, it indicates rebellion. It is also associated with Halloween and the supernatural (ibid). He (2009:162) shares Chapman's view and suggests that black has positive and negative associations. Positively, it is one of the favorite colours worn by the westerners on serious occasions. It is also the colour worn by celebrities and the members of the symphony orchestra to show respect to the audience and that in the service industry, high-ranking managers wear black. Negatively, black is the symbol of darkness in the western culture. In the Bible, black indicates the devil, evil, pain and misfortune (ibid).

Some English idioms that have positive or neutral connotations are: black belt (a belt that you can get when you win a game of judo or karate to show that you have reached a very high level); The Black Prince (King Edward III who was a brave soldier.); a black-tie dinner ( a dinner in which dinner jackets and black bow ties should be worn); Black Beauty (the name of a black horse which is the main character in a novel written in (1877) on which many other films and TV series are based); *black gold (oil); black diamond (British .English) (a lump of coal); black coffee/ tea (coffee or tea without milk).

Examples of English idioms that indicate negative connotations of black are: *black death (plague); black art (magic); black comedy/humour (comedy dealing with unpleasant events such as murder in a humourous way); black deeds/ lies (evil); *black future (a future without hope or a very depressing one); black sheep (a person who is different from the rest of their family or group and who is considered bad or embarrassing); black mark (something done or said by someone that make people think badly about them); black look (a look showing anger and hatred); *black day (a very bad day full of unpleasant events); black guard (a man who is dishonest and has no sense of what is right and what is wrong); black spot (a place, situation or event that is a problem or that causes a lot of problems); The pot calling the kettle black (a person who criticizes another for a fault he himself/herself has); black mass (a ceremony in which people worship the devil); blackout (a situation when the government or the police will not allow any news or information about a subject to be given to the public); to be in a black mood (to be angry or in low spirits); to blacken somebody's name or reputation (to say unpleasant things about a person in order to give people a bad opinion of that person); black leg (a person who continues to work while the other members are on strike); blackball (v) (to prevent somebody from joining a club or a group by voting against them).

In the field of business and economy, the connotations of black are mostly negative as indicated by black economy (business, activity or work done without the knowledge of the government to avoid paying tax); *black market (an illegal type of trade in which foreign money or goods that are difficult to obtain are bought and sold); Black Monday (Monday 19 October 1987, when prices on stock exchanges all over the world suddenly began to fall); Black Tuesday (29 October 1929, the day on which the New York Stock Exchange lost $\$ 9$ billion. It was the beginning of the Great Depression); *black list/ book (a list of the names of people, companies, products or countries that an organization or a government considers unacceptable and that must be avoided); black information (information kept by banks or other financial institutions about people who are not trusted to pay back the money which is lent to them); blackmail (the crime of demanding money by threatening to tell a secret to somebody about them).However, the idiom to be in the black is used positively to mean ( having money in your bank account).

He $(2009,162)$ states that the word Negro which was used to refer to the dark-skinned people who came from Africa has been replaced by the word black and is used for all aspects related to this race e.g., black English and that "Black is beautiful" has become the modern slogan of the black people (ibid). Another example is Black Power, which is 
the name of a movement supporting the rights and political power of the black people (ibid).

In Kurdish, as indicated by the idiomatic expressions, most of the connotations of black are negative. Black indicates sadness, mourning, bad luck, boredom, hatred, bad omen, pessimism, disease, genocide, crime, wrong doing, poverty, etc. Examples are: reş poş (of a person, all in black because of being sad or in mourning); Bali reşi be ser şwênêk da kêşa (to spread black wings over a place i.e. something causing a gloomy atmosphere or situation in a place); cerg reş bûn/ naw sik reş bûn (one's liver turning black/ one's inside turning black i.e. the state of becoming too annoyed and bored because of a continuous unpleasant situation); çare reş/ bexit reş (having a black fate/luck i.e. unlucky); desti reş (black hand, reference to a person who commits a crime); dem reş (black-mouthed i.e. a person who always tells bad omens); dil reş/ naw sik reş (black-hearted/to be black inside i.e. a cruel person with a heart full of hatred); *dwa rojeki reş (a black future i.e. bad and unpleasant future); le ber çaw reş bûn (to become black in somebody's eyes i.e. to be no more liked by somebody because of doing wrong things); pẽ reş (having black feet i.e. a person who is considered to bring bad omen to the place he/she goes to); reş bîn (to see black i.e. Pessimistic); reşgbigîr (the state of arresting everyone or sending everybody to war); reş kuji (black killing i.e. genocide); reş u rût (literally, black and naked meaning very poor); rû reş/ rû sia (black-faced i.e. a person who has been found guilty of doing something wrong or telling a lie); *roji reş (black day i.e. a bad day when bad events happen); *reşe bela (black disease (plague); reş helgeran (to turn black either because of disease or sadness); zman reş (black-tongued meaning a person who is shameless and uses dirty words); qele reş (the black bird i.e. the crow which is considered a sign of bad omen so that when a person utters a bad omen, they say he/she caws like a crow); ${ }^{*}$ Qel be qel deliẽ rut reş bi (A crow tells another crow, may your face turn black. This is the kurdish equivalent for The pot calling the kettle black); *bazari reş (black market); *listi reş (black list). Also, a black cat symbolizes evil.

Despite its negative connotations, black is considered a practical colour since it matches almost all the other colours; therefore, people young and old and both genders wear black and often match it with other colours and wear it for both sad and happy occasions e.g. people wear black for mourning and funerals and also for parties and other happy occasions. Elderly people prefer to wear black and other dark colours.

Black, in Kurdish, can also convey some positive or neutral associations. For example, poets describe a woman's hair, mole (somewhere on the face) and eyes as dark or black to indicate beauty as in çaw reş (having black eyes); xali resh (black mole); reş esmer (a person having a lovely dark colour). Black also indicates big size as in reşe xẽzan (black family i.e. a big-sized family; reşe zelam (a black person i.e. a big-sized person (The colour black here can also be replaced by blue to mean the same i.e. (şine zelam). Black indicates strength or strong belief in something as in reşe ba (black wind i.e. a strong wind or storm); reşe cû (a black Jew i.e. a Jew who has strong belief in his religion). Other idioms with black are ress belek (Kurdish folk dance in which men and women dance together; ${ }^{*}$ zẽri reş (black gold i.e. oil) and *reş pest (black-skinned i.e. black people).

Despite the fact that the connotations of black, as the examples indicate, are mostly negative in both languages, the idiomatic expressions, apart from the few ones with asterisks, do not match. For example, the negative use of black in the field of business is mostly related to the English culture. Kurdish does not have such expressions except black market. Kurdish, on the other hand uses black to indicate big size, genocide, poverty, etc. which are not found in English.

\section{Red: Sûr/ Al}

Morton, (1995-2017) states that the prehistoric people considered red as the colour of fire, blood, energy, and primal life forces and most of the connotations of red today come from past associations. He also mentions that red symbolizes extremes, passionate love, seduction, violence, danger, anger, and adventure. He adds that red is also associated with magic and religion. In Christianity it is a symbol of crucifixion of the Christ. It is the most popular colour used on flags; it is also the international colour for stop in traffic (ibid).

Makarevicius (2014) shares most of the above meanings of red and adds that red, being the color of blood, relates to life itself. He suggests that red is associated with fire, energy, passion and love, but 
also indicates rage, war, provocation and revolution and that in Greek mythology, it referred to the planet Mars and god of war. He also states that in Europe and USA red (with green) is a symbol of Christmas, while red with white is a symbol of Valentine's Day (ibid).

The following idiomatic expressions indicate some of the above positive and negative connotations: red-hot (of a person, showing strong feelings); red- hot (of a subject or an issue, exciting and of great interest to people); *red-blooded (full of strength and energy); a red rose and a red heart are symbols of Valentine Day). Red can also indicate respect and warm greetings as in*to roll out the red carpet for somebody (to warmly receive somebody) and happiness and joy as in paint the town red (to go to different bars and clubs and enjoy yourself).

Examples of negative connotations of red are: a red rag to a bull ((British English) like waving a red flag in front of a bull (American English) (something that is likely to provoke somebody or make somebody very angry); red in tooth and claw (involving opposition or competition that is violent and without pity); *to see red (to be very angry); on red alert (warned of or prepared for a dangerous situation); red card (in football (soccer) a card shown by the referee to a player who has broken the rules of the game and not allowed to play for the rest of the game); *to give somebody the red light (to prevent somebody from doing something); to be in the red (to owe money to your bank because you have spent more than you have in your account); *to go through the red light/ jump the red light (to not stop when there is the red traffic light).

Red can also indicate embarrassment as in *beet red (of the face bright red or pink because of being embarrassed or ashamed); *red-faced (with a red face either because of embarrassment or anger).Other connotations of red are indicated by the following idioms: red herring (an unimportant fact, idea, event etc., that takes people's attention away from the important ones); *red line (an issue or a demand that a person or a group refuses to change their opinion about during a disagreement or a negotiation); redneck (an offensive word used for a person in a country area of the US, who has little education and has strong conservative political opinions); red tape (official rules that seem more complicated than necessary and prevent things from being done quickly); *red-head/headed (a person with red hair).

He $(2009,161)$ mentions that red can symbolize cruelty and disaster as in: red revenge/ red battle (a cruel battle in which a lot of lives are lost); red revolution (violent revolution); *the red flag (a signal to indicate danger); murder as in * to have red hands (to commit murder); to be caught red-handed (to be caught while doing something illegal or wrong); red ruin (fire, as a disaster); red ink (deficit ). He also states that red can carry positive connotations like bravery and courage as in red-blooded and happiness as in the red-letter day (a day when some happy or exciting events happen).

In Kurdish, the idiomatic expressions indicate that red has positive and negative connotations. The positive connotations include joy, love, virginity, beauty, youth, health, bravery and martyrdom. For example, the flag of Kurdistan includes red to symbolize the blood of martyrs of Kurdistan who have sacrificed their lives for the freedom of Kurdistan and the dignity of the Kurdish people (Izzadi, 2008). Young people wear red for parties, weddings and other happy events. In the past brides used to wear red Kurdish uniforms. A red rose is a symbol of love.

In poetry, red (instead of pink) is used to describe a woman's lips or cheeks as a sign of beauty as in lew al/ gona al (of a woman having red lips/ cheeks); sûr wek xwên/ wek denûki kew (as red as blood/ as red as a partridge's beak indication of the depth of the red colour which is a sign of beauty). Red cheeks indicate health, beauty and youth as in suru spi (literally red and white i.e. a person with white skin and pink cheeks); sûr u sepan (collocation literally meaning having a glowing complexion which is a sign of good health). Red face (for women) is a symbol of chastity as in Ru sûr bi. (literally, may you keep a red face, said to a woman to mean: May you stay chaste. Red here can be replaced with white with the same meaning). Red eyes and red mouth indicate bravery as in çaw sûr (red-eyed i.e. brave and challenging); dem sûr (redmouthed i.e. brave). The word red in the English idiom red-blooded is replaced by the word warm in Kurdish as in the idiom *xwen gerim (warmblooded to indicate strength and energy) and both words are qualities that describe blood. Red is also used to indicate respect and warm greetings as in *Fershi sûri bo raxist (rolled out the red carpet for somebody i.e. received somebody very warmly). 
Negative meanings of red include bloodshed, embarrassment, anger, fire, rebellion, danger, warning, threat, murder etc. The English idiom beet red has the Kurdish equivalent blood red to indicate shyness or embarrassment as indicated by the idiom demuçawi wek xweni lehat (His/her face turned blood red). Red eyes can indicate anger, threat, rebellion as in çaw le sûrkirdnewe (to redden one's eyes at somebody i.e. to threaten somebody); *çawi sur bwe (literally meaning, one's eyes have turned red, i.e. one has become very angry; or has become conceited or rebellious); sûrkirdnewe (can mean frying food or toasting bread until red in colour, or it can mean to find out the truth about something said by somebody);. Red hands indicate murder as in *dest sûr bûn/ kirdin (to make one's hand red / one's hand having become red i.e. of a person having committed murder). Red can also indicate embarrassment as in *sûr helgeran/ sûr bunewe (to turn red either because of being shy or embarrassed); Red can indicate danger and warning as in * Glopi sûri bo dagirsand (to give somebody the red light i.e. to warn somebody not to do something;otherwise, the results will not be good); *alay sûr (red flag as a sign of war or danger); *Heli sûr (the red line i.e. something which is considered a taboo, therefore one shouldn't talk about it). (There is a slight difference in meaning between the Kurdish version and the English version above). Le glopi sûri da/ glopi sûri bezand (in traffic, jumped the red light). In Kurdish and also in English the colour orange is sometimes replaced by red. For example fire has an orange colour but it is described as red in both languages as in the English expression red ruin (reference to fire) and the Kurdish expression Agre sûre le min dure (Red fire, keep away from me, said when a person wants to keep away from other people's problems instead of helping them); also in the English red-headed and the Kurdish *ser sûr (redheaded/haired meaning a person with red hair) red has replaced orange.

What is observed from the above mentioned examples is that both languages share different connotations indicated by red such as anger, embarrassment, murder, energy, love, beauty, joy, danger and they have somehow similar idiomatic expressions for these connotations (see the ones with asterisks); however, there are some connotations that belong to English only e.g. using red to indicate deficit as in red ink, to be in the red, and idioms like red-neck and red herring, while using red face to indicate chastity, red-mouthed to indicate bravery and red eyes to indicate anger and threat are examples of idioms specific to Kurdish.

\section{Green: Sewz/Kesk}

Kleynhans (2007) states that "green is the largest family discernible to the human eye, which is why our feeling towards green may be so varied". Green has positive connotations including environment, growth and renewal in spring, fertility, freshness, nature, youth, health, peace and calmness, things that are cool and refreshing, and wealth (ibid). Similarly, Dunn (2014) suggests that green is the most pervasive and the dominant colour of nature that symbolizes youthfulness, strength, freshness healthiness, restfulness calmness, fertility, dynamism, and generosity. She also adds that green has a soothing, relaxing and healing effect on our physical and mental well-being; therefore, it is a suitable colour for nurses to wear during their work in hospital. In the business world, as suggested by Dunn (2014), green indicates growth and prosperity. Morton (2011) states that green traffic lights and green fire exit signs symbolize safety all over the world and that green is a sign of good luck in most western cultures as indicated by a green shamrock.

The following English idioms indicate some of the above mentioned connotations of green: green politics (one that supports the protection of the environment); The Green Party (a British political party that aims to protect the environment); The Green Party of the United States (US political party which aims to protect the environment and supports social justice); to have green fingers (British English)/ to have a green thumb (American English) (to be skilful at farming); greener pastures (better places or jobs); * greenery (attractive green leaves and plants); The grass is greener on the other side of the fence (of people, not satisfied with what they have and always think that other people are in a better situation or believe that things in other places are always better than what is found in their local area); the green room (a room where actors rest after they act their role); green house (a building with glass sides and a glass roof for growing plants in); ${ }^{*}$ greens (green vegetables); green roof (a roof with plants grown on it to keep the house cool in summer and warm in winter); ${ }^{*}$ to give green light to somebody/ to get green light (to 
let him/her do something/ to be given permission to do something.); the Green Man (a figure of a person that has a green light shining through it at traffic lights. In Britain, the green man lights up when the traffic has stopped, to show people that it is safe to cross the road). Another meaning is (an image of a man surrounded by green plants, trees, etc. which is an old symbol of fertility in Britain); * green grocer (a shop keeper who sells fruit and vegetables); green card (a document that legally allows somebody from another country to live and work in the US). In British English it is used to refer to (an insurance document that you need when you drive your car in another country); greenback (an American dollar note). To green something or somebody means (to create parks and green areas with plants and trees or to raise awareness about environment protection).

Green, in English, also has negative connotations including: envy, lack of experience, gullibility, immaturity, nausea, rawness, sourness, and the alien creatures coming from other plantes e.g., little green Martians (Kleynhans, 2007). Some of the idiomatic expressions that show these negative connotations are: green with envy (very jealous); green-eyed (very jealous); the green-eyed monster (used as a reference to jealousy); green as grass (of a person, still very young and lacking experience); *green (of fruit meaning unripe); greenhorn (a gullible person who has little experience; therefore, he can be easily tricked); * green about/around the gills (of a person, sick and about to vomit); greenwash (disapproving, activities by a company or an organization that are intended to make people think that it is concerned about the environment, even if its real business actually harms the environment.

Other expressions with green include: The green welly brigade (humorous or disapproving, rich people who live or like to visit the countryside); green belt (an area of open land around a city where building is strictly controlled); Green Beret (a member of the US army Special Forces); green field ( used to describe an area of land that has not yet had buildings on it, but for which building development may be planned); the greenhouse effect (the problem of the gradual rise in temperature of the earth's atmosphere, caused by an increase of gases such as carbon dioxide in the air surrounding the earth, which trap the heat of the sun); greenhouse gas (any of the gases that are thought to cause the greenhouse effect, especially carbon dioxide); green audit (an official examination of the effect of a company's business on the environment).

Kurdish, based on the examples found in the Kurdish idiom books used in this study, has very few expressions with the colour green most of which carry positive connotations. Green symbolizes nature, environment, spring, life, rebirth, plants and vegetables and in this sense and with some idiomatic expressions, it is often replaced by blue (şin). The following expressions indicate some of the above meanings: *sewze (green vegetables); *sewze froş (green grocer); *sawzayi/ şinayi (greenery); Hiçi le sewiz/şin nabet (literally, nothing becomes green/blue out of something i.e. of an effort doesn't give any results) .Green is used in the flag of Kurdistan as a symbol of the beauty of the nature and the landscapes of Kurdistan (Izadi, 2008)).

Green is also connected with Islam religion and is a sign of sacredness. Muslim religious men often wear green belts and consider green as a sacred colour; hence, the idiom Desti sawz debêt (literally meaning one's hands become green i.e. of a person, he becomes a saint if he kills somebody who is wicked and hated by people). Traditionally, when people visit holy shrines, sometimes they take a piece of green cloth and leave it on the grave of the holy person in the hope that their wishes may come true, and other visitors would take strips from the green cloth and tie it round their wrists for healing from physical or mental illnesses. Green is also a sign of safety as indicated by the green traffic light as in *Glopi sawzi bo dagirsand (to give green light to somebody i.e. to allow somebody to do something). The only negative connotation of green is when it is used to indicate a person's colour because of sickness as in *kesk helgeran (to turn green, meaning to turn pale because of feeling sick. Green in this example can be replaced by yellow zerd helgeran (to turn yellow because of sickness) or black res helgaran (to turn black because of sickness).

As the above English and Kurdish examples show, English, as compared to Kurdish has more idioms with green and most of them belong to the English language and culture. The similarities can be found in using green to indicate environment and vegetables and also when referring to sickness. The other difference is that in Kurdish, green, when 
referring to environment and green vegetables or planting can be used interchangeably with blue and when referring to sickness, it can be interchanged with yellow or black.

\section{Yellow: Zerd}

Kleynhans (2007) suggests that yellow is the most easily perceived colour, especially when it is set against black; therefore, yellow against black is often used in warning signs. According to Kleyhans, yellow's positive connotations include cheerfulness, sun, gold, happiness, vitality, hope and optimism. Makarevicius (2014) states that "yellow is reflective and luminous". He adds that in most cultures, yellow is associated with the sun which is "the dominant force in the solar system". And that it also indicates wisdom, glory, light, joy, enthusiasm and optimism According to the same source, in Greek mythology, yellow is the color of Mercury, the messenger of the gods and the communicator of mental and spiritual enlightenment.

Some of the above connotations can be observed in idioms like yellow brick road (a course of action that a person takes thinking that it leads to good things); yellow ribbon (In the US, a piece of yellow material that a person ties around a tree as a sign that they are thinking about a person who has gone away, especially a soldier fighting in a war or somebody taken as hostage or prisoner hoping that the person will soon return safely). Despite the positive meanings of yellow, most of the English idiomatic expressions with yellow indicate negative connotations. For example, Kleynhans (2007) associates yellow with caution as indicated by the yellow traffic-light; sickness, betrayal and cowardice and Makarevicius (2014) associates it with aging, illnesses (such as jaundice), decayed teeth, infection and pus. The following idioms show some of these negative meanings of yellow: yellow-belly/ yellow-bellied (of a person, cowardly and easily frightened); yellow streak (down someone's back) (a tendency toward cowardice); yellow card in football is (a card shown by the referee to a player as a warning about bad behaviour); yellow dog (a despicable (evil) person or thing); a yellow flag on a ship shows that somebody has or may have an infectious disease; yellow fever (an infectious tropical disease that makes the skin turn yellow and often causes death); *yellow skin (jaundice); yellow journalism (newspaper reports that are exaggerated and written to shock readers); yellow is (an offensive word used to describe the light brown skin of people from some East Asian countries); yellow (disapproving, meaning easily frightened); yellow line (in Brtain) a yellow line painted at the side of a road to show that you can only park your car there at a particular time or only for a short time); double yellow lines (two yellow lines meaning you cannot park your car there at all).

In Kurdish, idiomatic expressions with yellow are few in number and has some positive associations such as the sun, light, brightness, gold and hence, it is used in the flag of Kurdistan to represent the source of life and light, while the blazing golden (yellow) sun emblem at the center is a cultural symbol representing wisdom in the ancientKurdish Zoroastrianism and Yezidi religion s (Izadi 2008). It also indicates beauty when combined with red as in zerd $\mathbf{u}$ sûr (yellow and red, of children or young people, lovely and beautiful). Poets use yellow/golden when describing a woman's hair or the beauty of the sun or the sunrise.

However, yellow has also negative and neutral connotations such as embarrassment as in rû zerd (yellow-faced, of a person embarrassed because he/she has done something wrong); sickness or fear as in wek za'farani zerdi lehat (turned as yellow as saffron i.e. turned very yellow either because of fear or sickness or embarrassment); zerd helgeran (to turn yellow either because of sickness or fear or embarrassment); reng zerd (to have a yellow/pale colour because of sickness or sadness); *zertik/ zerduyi (jaundice). Yellow also indicates the state of being unripe as in zerd $\mathbf{u}$ zol (of fruit meaning unripe); Yellow is also used to show that a tumour or an infection has become soft and ripe and ready to ooze pus as indicated by zerd bûn (to become yellow because full of pus). In cooking, zerdkirdin means to halfcook vegetables like okra, green beans, etc. for the purpose of cooking it later or to keep them in the freezer).

The connotations of yellow in the two languages are very different. They only match when indicating, sickness or fear, but the idiomatic expressions that express these connotations are quite different. Yellow face in Kurdish doesn't only indicate fear or cowardice; it can also indicate embarrassment, sadness or sickness.

\section{Blue: Şîn}


According to Makarevicius (2014), blue symbolizes calmness, peace, loyalty, truth, dignity, royalty and contemplation, but also sadness. It is associated with the sky and the sea, and in many cultures, it is the symbol of infinity and mystery. The same source further adds that for the ancient priests and physicians of Britain known as the Druids, blue is the color of harmony, truth, and wisdom while in Christianity, it is a symbol of Christ's hue, and the color of heaven where he resides. Blue also symbolizes the color of "The Divine Light" and the Virgin Mary. In general, blue is considered a non-threatening color, which everyone can use (ibid).

In addition to the above meanings, Kleynhans (2007) associates blue with spirituality, royalty aristocracy, tranquility, conservatism, loyalty, dependability, security, introversion, sadness, depression, unexpected things, and low class. According to Dunn (2014), in the UK, blue is the colour of healthcare. The National Health Service logo is blue and nurses' uniforms are often blue.

Some of the above positive connotations are expressed by the following idiomatic expressions: true blue (strongly supporting something/ strongly supporting the conservative party); blue blood (a member of a royal or socially important family); blue helmet (a member of a United Nations force that is trying to prevent war or violence in a place); blue riband/ribbon (an honour, sometimes in the form of a blue ribbon, given to the winner of the first prize in a competition); a blue-riband event (a very important event); blue-eyed boy (the favourite person of somebody. or a worker favoured by his/her boss); blue flag (In British English it may refer to a blue flag used in motor racing to show that a driver who is much further ahead is trying to pass, or it may mean an award given to beaches in Europe that are clean and safe); blue-sky (involving new and interesting ideas which are not yet possible or practical).

Negative associations of blue can be observed in the following expressions: to feel blue (to feel depressed); baby blues (a depressed feeling that some women get after the birth of a baby); blues (a type of slow sad music with strong rhythms developed by the African American musicians in the southern US.); to be between the devil and the deep blue sea (to be in a difficult situation where there are two equally unpleasant or unacceptable choices); *do something until you are blue ( try to do something as hard or as long as you possibly can but without success); *hit somebody black and blue (to hit somebody until they are covered with bruises); blue baby (a baby whose skin is slightly blue at birth because there is something wrong with its heart); blue movie (a movie that contains indecent or morally offensive scenes); scream blue murder (British English) (to scream loudly and for a long time especially to protest against something.); blue murder (a violent scene); Other connotations of blue are indicated by the following idioms: out of the blue (suddenly or unexpectedly); a bolt from the blue (a sudden or unexpected event or news) blue stocking (old fashioned, a welleducated woman who is more interested in ideas and studying than in the traditional feminine issues); blue-collar (a worker who works in a factory (reference to low or working class); like blue blazes (repeatedly); once in a blue moon (very rarely); blue-on-blue (in a war, used to describe an accident or attack in which people are hit by a bomb or weapon that is fired by their own side).

In Kurdish, as mentioned above, blue (şîn) is sometimes used interchangeably with green (sawz) especially when talking about the environment and planting as in şînayi (greenery) şîn/ sawz bûn (literally to become blue/green, of a plant i.e. to grow).

Blue is a symbol of beauty when used by poets to describe nature e.g. the sky, rivers and lakes or a woman's blue eyes It is also believed that blue protects from evil eye; hence, the belief that wearing blue clothes or beads wards off evil eye as in lepkey şîn (a blue amulet or blue beads worn by some people to be protected from evil eyes). Dark blue or indigo is also a colour worn in mourning and funerals. Blue, in Kurdish, has other connotations like physical efforts especially when combined with black or purple as in *areqi reş u şini derkird (literally meaning, of a person, perspired black and blue sweat i.e. became very tired because of exerting physical efforts) or with purple as in şîn u mor bûnewe (of a person, to become blue and purple because of laughing or crying hard). Blue is also used to indicate bruises on one's body as in *şîn u mur bûnewe (to become blue and purple, of part of the body, to be badly bruised). Blue can also indicate big size as in şine zelam (a big-sized person); şîne dro (a blue lie i.e. a big lie). Ser şîn kirdin (literally meaning to dye one's head/hair 
blue i.e. to put mud on one's head to express deep sadness because of the death of a loved person. This custom was practiced in the past but no more or very rarely nowadays.

As the examples show, blue has the least similarity in connotations and idiomatic expressions in the two languages. There is partial similarity in the general meaning when blue is used to indicate (exerting physical efforts) as in the English idiom do something until you are blue and the Kurdish areqi reş $u$ şini derkird; however, while the English idiom connotes failure despite trying hard, the Kurdish one connotes success in achieving a hard task. Also, there is some partial similarity in meaning between the English hit somebody black and blue and the Kurdish şîn u mor bûnewe (to become blue and purple, of part of the body to become bruised) since both of them refer to bruises on the body resulting from some violent act or accident. While the English idiom shows that the bruise is a result of being hit by somebody, the Kurdish idiom does not specify the reason of the bruise. It can be due to any violent act or accident. There is also difference in the colours used in these two idioms: the first English idiom contains only blue while the Kurdish uses black and blue; in the second one, the English idiom uses black and blue while the Kurdish one uses blue and purple.

\section{RESULTS:}

The results of the study can be summarized in the following points:

a. Colours have positive and negative connotations with some colours being more negative, and some more positive, while some are in between.

b. According to this study 5 , the order of the frequency of the use of the six basic colours in idiomatic expressions in English is: black (36), green (32), red (30), white (26), blue (24) and yellow (15). In Kurdish, black (33), white (21), red (20), blue (9), yellow (9) and green (7).

c. The positive-negative ratio of the six colours is: English: black (11 p-25 n); green (20 p-12 n); red $(8 \mathrm{p}-21 \mathrm{n})$; white $(16 \mathrm{p}-10 \mathrm{n})$; blue (14 p-10 $\mathrm{n})$; and yellow ( $3 \mathrm{p}-12 \mathrm{n}$ ) (Note: the positive ones also include the neutral ones).

Thus, the more positive colours in English are: green, white and blue, while the more negative colours are: black, red and yellow.

Kurdish: black (10 p-23 n); white (17 p- 4 n); red (11p-9 n); blue (4 p-5 n); yellow (3p- $6 n)$; green $(5 p-2 n)$. The more positive colours are white and green. The more negative colours are black and yellow while red and blue are in between.

d. Many of the colours combine with a body part to express the quality, appearance, behaviour, feelings or attitudes of a person. This is especially true with regard to Kurdish.

e. In Kurdish green and blue can be used interchangeably when referring to greenery or vegetables in general or planting, but this is not found in English.

f. The number of the totally or partially similar idiomatic expressions with the 6 colours in English and Kurdish are: black (8), red (10), white (8), green (4), yellow (3) and blue (2) (See the idiomatic expressions with asterisks for each colour). This shows that the similarities are far fewer than the differences and proves the validity of the hypothesis that the symbolic use of colour terms in idiomatic expressions is, to a great extent, culture specific.

\section{Conclusion}

This study concludes that despite similarities in the general meanings and connotations of colours across cultures, each culture has its own traditions and customs that distinguishes it from other cultures and this is reflected in their perception of colours and in their idiomatic use of colour terms. However, with the recent globalization movement there is a growing trend towards more similarities in colour symbolism across cultures because, as stated by, Kleynhans (2007, 46), "Colour is a universal language that crosses cultural boundaries in our electronically/technologically/satellite linked Global Village".

The Kurdish phonetic symbols and their equivalents

\begin{tabular}{|c|c|}
\multicolumn{2}{|c|}{ in English } \\
\hline $\begin{array}{c}\text { Kurdish Phonetic } \\
\text { Symbol }\end{array}$ & $\begin{array}{c}\text { Equivalent in } \\
\text { English }\end{array}$ \\
\hline$/ \mathrm{a} /$ & $/ \mathfrak{x} /$ \\
\hline$/ \hat{a} /$ & $/ \mathrm{a} / /$ \\
\hline$/ \mathrm{e} /$ & $/ \mathrm{a} /$ \\
\hline$/ \mathrm{e} /$ & $/ \mathrm{e} /$ \\
\hline$/ \mathrm{u} /$ & $/ \mathrm{u} /$ \\
\hline$/ \hat{\mathrm{u}} /$ & $/ \mathrm{u} / /$ \\
\hline
\end{tabular}




\begin{tabular}{|c|c|}
\hline /i/ & $/ \mathrm{I} /$ \\
\hline /î/ & /i:/ \\
\hline $1 \mathrm{o} /$ & $10 /$ \\
\hline$/ \hat{\mathrm{o}} /$ & /o:/ \\
\hline$/ \mathrm{b} /$ & $/ \mathrm{b} /$ \\
\hline$/ \mathrm{p} /$ & $/ \mathrm{p} /$ \\
\hline$/ \mathrm{d} /$ & $/ \mathrm{d} /$ \\
\hline$/ \mathrm{t} /$ & $/ \mathrm{t} /$ \\
\hline /f/ & $/ \mathrm{f} /$ \\
\hline$/ \mathrm{v} /$ & $/ \mathrm{v} /$ \\
\hline$|\mathrm{z}|$ & $|z|$ \\
\hline$/ \mathrm{s} /$ & $/ \mathrm{s} /$ \\
\hline / / / / & $/ \mathrm{d} /$ \\
\hline |ç/ / / & $/ \mathrm{t} \mathrm{g} /$ \\
\hline $\mid \mathrm{j} / / \mathrm{j} /$ & $\mid 3 /$ \\
\hline /ش/ شș/ & $\mid \mathrm{g} /$ \\
\hline$/ \mathrm{h} /$ & $/ \mathrm{h} /$ \\
\hline$/ \mathrm{h}$ '/ & $\begin{array}{l}\text { Not found in English } \\
\text { but pronounced like } \\
\mathrm{h} / \mathrm{C}\end{array}$ \\
\hline$|x /| \dot{\mid x} \mid$ & $\begin{array}{c}\text { Not found in English } \\
\text { but pronounced like } \\
\text { /k/ }\end{array}$ \\
\hline$/ \ddot{x} / \mid \dot{\varepsilon} /$ & $\begin{array}{l}\text { Not found in English } \\
\text { but pronounced like } \\
/ \mathrm{g} /\end{array}$ \\
\hline |ع| /?/ & $\begin{array}{l}\text { Not found in English } \\
\text { but pronounced like a } \\
\text { glottal stop }\end{array}$ \\
\hline$/ \mathrm{k} /$ & $/ \mathrm{k} /$ \\
\hline$/ g /$ & $/ g /$ \\
\hline /q/ / / & $\begin{array}{l}\text { Not found in English } \\
\text { but pronounced like } \\
\text { /k/ }\end{array}$ \\
\hline$/ \mathrm{r} /$ & $/ \mathrm{r} /$ \\
\hline$/ 1 /$ & $/ 1 /$ \\
\hline$/ \mathrm{m} /$ & $/ \mathrm{m} /$ \\
\hline$/ \mathrm{n} /$ & $/ \mathrm{n} /$ \\
\hline$/ \mathrm{w} /$ & $/ \mathrm{w} /$ \\
\hline$/ \mathrm{y} /$ & /j/ \\
\hline
\end{tabular}

\section{REFERENCES}

Ali, Jalal Mahmood. (1981). Idyom le zmani Kurdida (Idioms in Kurdish Language). vol.1. Baghdad: Husam for Printing.

Ali, Jalal Mahmood (2001). Idyom le zimani Kurdida. (Idioms in Kurdish Language). vol. 2. Sulayma:ni: Sardam for Printing and Publishing.

Anderson, Wendy and Ellen Bramwell. (2014). "Metaphorical Spectrum:Surveying Colour Terms in English", University of Glasgow. In Colour studies: A broad spectrum ed. by Wendy Anderson, Carole P. Biggam, Carole Hough and Christian Kay. (2014). Amsterdam/ Philadelphia: John Benjamins Publishing Company, pp. 140153.

Berlin, Brent and Paul Kay. (1991). Basic Color Terms: Their Universality and Evolution. Berkeley: University of California Press.

Chapman, Cameron. (2010). "Colour theory for designers Part 1: The meaning of colours". Available at: https://www.smashingmagazine.com/2010/01 /color-theory-for-designers-part-1-the-meaningof-color/ [Accessed 20/3/2018].

Cherry, Kendra (2018). Reviewed by Steven Gans, 'The Opponent Process Theory of Colour: Understanding how we see colour vision" Available at: https://www.verywellmind.com > Psychology > Theories > Cognitive Psychology Collins Coubuild Idiom's Dictionay. (1996). Harper Collins Publishers.

Crone, Robert A. (1999). A History of Colour: The Evolution Theories of Light and Colour. Kluwer Academic Publishers.

De Bortoli, Mario and Jesús Maroto (2001). "Colours across cultures: Translating colours in interactive marketing communication"'. Available at: https:// www.semanticscholar.org/paper/Colo urs-Across-Cultures\%3A-Translating-Coloursin-In-Bortoli Maroto/91d873c75769968cca43182419730dbe183 5504d. [Accessed 9/6/2015].

Douma, M. Curator. (2008). "Colour Art and Mind: Micrconsciousness". In Causes of Colour. Available at: 
http://www.webexhibits.org/causesofcolor/3.h tml.

Dunn, Alison, 2014. "The meaning of colour: The cultural and ethnic aspects of colour use". Available

at: file:// /E:/20162017/colourHTML/Alison\%20D unn $\% 20$ The $\% 20$ meaning $\% 20$ of $\% 20$ colour.htm [Accessed 22/8/2016].

Foster, Geraldine Ann.(n.d.) 'The language of colour". Available at: www.fpweb.it/public/foster/.../shape-colour-logosstudent-reading.pdf. [Accessed 31/7/2016].

Gage, John. (1999). Colour and Meaning: Art, Science and Symbolism. Berkeley and Los Angeles: University of California Press.

Goethe, Johann Wolfgang Von. (1840) Goethe's theory of colour London: John Murray Albemarle Street 1840. Translated from the German with Notes by Charles Lock Eastlake. (1941). London: William Clower and Sons, Stamford Street.

Hardin, C.L. (2013). "Berlin and Kay Theory". New York: Syracuse University, Department of Philosophy, in Encyclopedia of Color Science and Technology. DOI 10.1007/978-3-642-27851-8_622. Springer Science+Business Media New York 2013.

He, Guimei. (2009). "English and Chinese cultural connotation of color words in Comparison". Qingdao University of Science and Technology Qingdao Asian Social Science.5 (7) pp. 160-163. Available at: http://bartos.web.elte.hu/ma/color-culture-EC.pdf. [Accessed 20/10/2014]

He,Guimei, (2011). "A comparative study of color metaphors in English and Chines"'. In Theory and Practice in Language Studies, 1 (12), pp. (18041808), Qingdao University of Science and Technology Qingdao, China. Available at: https://pdfs.semanticscholar.org/08fb/9995682 801a456dd80d4eb9f6335d82e4d58.pdf[Accessed $24 / 8 / 2016]$

Izady, M.R. (2008). 'The National Flag of Kurdistan'. In Encyclopaedia Kurdistanica. Archived from the original on 1 May 2008. Retrieved 6 June 2008.
Kay, P. and C. McDaniel (1978). 'The Linguistic Significance of the Meaning of the Basic Color Terms'. In Language, 54, pp. 610-646.

Kleynhans, J. H. (2007). 'The use of colour as a tool for propaganda". In Interim: Interdisciplinary Journal, 6 (1) 46-53. Available at: http://ir.cut.ac.za/bitstream/handle/11462/399 $\angle$ Kleynhans, \%20J.H..pdf?sequence $=1$ [Accessed 20/10/2014].

Koelbing, H.M., (1988). 'The history of color theories" (Zur Geschichte der Farbenlehre), Klin Monbl Augenheilkd, 192(2), (176-82), Abstract only, Medizinhistorisches Institut der Universität Zürich. Available at: https://www.ncbi.nlm.nih.gov/pubmed/32834 27 [Accessed 19/3/2018].

Kurdish Academy of Languages (2016) "Kurdish language"www.kurdishacademy.org/?q=node/ $\underline{1}$

Kurdish Academy of Language. (2018). "Kurdish Language".

https://www.revolvy.com/page/KurdishAcademy

Lucy, J. A. (1996). 'The Scope of Linguistic Relativity: An Analysis and Review of Empirical Research". In John J. Gumperz and Stephen Levinson (Eds.), Rethinking Linguistic Relativity. Cambridge: Cambridge University Press. 37-69.

Makarevicius, Algirdas, (2014). "Culture and colour". Available at: http://alslectures.webs.com/cultureandcolor.ht $\underline{\mathrm{m}}$ [Accessed 15/9/2014]

Morton, J.L. (2011). "Color matters". In Colour Matters Newsletter. Available at: https://www.colormatters.com.[Accessed 28/2.2017].

National Program on Technology Enhanced Learning (NPTEL) Courses, Module 13: Lecture 36 (2012). "Color and society: Single colour meaning" Available at: file://E | /color_in_design/lecture36/36_1.htm [8/17/2012 2:30: [Accessed 20/10/2014] Oxford Advanced Learner's Dictionary, 8th edition. (2010) Oxford University Press.

Palmer, F.R. (1981), Semantics (2nd ed.). Cambridge University Press. Pathak, Apeksha. (2012). "Color code: interpretations and perceptions of colors in 
our world". QlikView Technical Brief. Available at: https://community.qlik.com/docs/DOC$\underline{3173}$ [Accessed 2/10/2014]

Philip, Gill., 2011. Colouring meaning: collocations and connotations in figurative language. [e-book] Amesterdam: John Benjamin Publications.

Regier, Terry and Kay, Paul. (2009). 'Language, thought and colour: Whorf was half right. In Trends in Cognitive Sciences vol. $x x x$ No. $x$.

Salim, Jamal Azmi \& Mohammad Mehawesh. (2013)."'Color idiomatic expressions in the translation of Naguib Mahfouz's novel "The Thief and the Dogs": A case study" In the International Journal of English Linguistics, 3 (4) pp. 107-116.Department of English Language and Translation, Faculty of Arts, Zarqa University, Jordan. Available at: http://www.ccsenet.org/journal/index.php/ije 1/article/view/29057 [Accessed 24/8/2015].

Saundres, B. (1995). "Disinterring Basic Color Terms: A Study in the Mystique of Cognitivism". In History of the Human Sciences, 8 (7): 19-38.

Sharaf Fatima. (2005). Atlas Dictionary of English Idioms English-Arabic. Edited by Sara Rashwan. Atlas for Publishing.
Shareef, Abdul-wahab Kanabi. (2005). Ferhengi Idyom le Zmani Kurdi. (A Dictionary of dioms in Kurdish Language). Sulaymani: Ministry of Culture.

Swenson, Rivka. (2010). "Optics, Gender, and the Eighteenth- Century Gaze: Looking at Eliza Haywood's Anti-Pamela". In the EighteenthCentury Journal, Volume 51, No. 1-2, PP27-4). University of Pennsylvania Press DOI: 10.1353/есу. 2010 .

Wagner, Brain Thomas and Donald Kline. (2002). The History of Colour Vision Science: Bases of Colour Vision". University of Calgary. Available at: $\quad$ https://psyc.ucalgary.ca/PACE/VALab/Brian/history.htm

Wardhaugh, Ronald. (1986). An Introduction to Sociolinguistics.Basil Blakwell Inc.

Zelanski, Paul \& Mary Pat Fisher, (1995). Colour design Principles and Problems [e-book\}, Colour chapter pp. 227- 250. Wadsworth. Available at: http://www.utdallas.edu/ melacy/pages/2D_ Design/Color_DesignPrinciplesProblems.pdf [Accessed 4/1/2018].

${ }^{1}$ Central Kurdish dialect (also called Sorani dialect) is "the language of a plurality of Kurds in Eastern Kurdistan (Kurdistan in Iran) and Southern Kurdistan (Kurdistan in Iraq), with about 8 million speakers" (Kurdish Academy of Language 2016). "Central Kurdish is one of the two official languages of Iraq, along with Arabic, and is in political documents simply referred to as Kurdish" (Kurdish Academy of Language, 2018).

2The English colour idiomatic expressions have been taken from the following sources: Atlas Dictionary of English Idioms (2005), Collins Coubuild Pocket Idiom's Dictionay, (1996)., Macmillan English Dictionary 2nd ed. (2007) and Oxford Advanced Learner's Dictionary $8^{\text {th }}$ ed. (2010).

3 The Kurdish idiomatic expressions are taken from: Ali, Jalal Mahmood. (1981). Idyom le Zma:ni Kurdida. (Idioms in Kurdish Language). Vol 1.; Ali, Jalal Mahmood (2001). I: dyom la Zima:ni: Kurdi:da. (Idioms in Kurdis Language). vol. 2. and Shareef, Abdul-wahab Kanabi. (2005). Ferhengi: I: dyom le Zmani Kurdi. (A Dictionary of Idioms in Kurdish Language).

4 The study also includes idiomatic expressions, which are found in Kurdish and not mentioned in the sources used. These are included by the researcher after consultation with experienced persons.

${ }^{5}$ The study has covered most (not all) of the idiomatic expressions for each colour in the two languages; therefore, the given numbers are only limited to this study. 